THE PROFESSIONAL LITERARY AGENT IN BRITAIN, $1880-1920$ 
This page intentionally left blank 


\section{The Professional}

Literary Agent in

Britain, 1880-1920

\section{MARY ANN GILLIES}

UNIVERSITY OF TORONTO PRESS

Toronto Buffalo London 


\section{www.utppublishing.com}

(C) University of Toronto Press Incorporated 2007

Toronto Buffalo London

Printed in Canada

ISBN 978-0-8020-9147-5

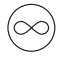

Printed on acid-free paper

\section{Library and Archives Canada Cataloguing in Publication}

Gillies, Mary Ann, 1959-

The professional literary agent in Britain, 1880-1920 / Mary Ann Gillies.

(Studies in book and print culture)

Includes bibliographical references and index.

ISBN 978-0-8020-9147-5

1. Literary agents - Great Britain - History - 19th century. 2. Literary agents Great Britain - History - 20th century. 3. Authors and publishers - Great Britain - History - 19th century. 4. Authors and publishers - Great Britain History -20 th century. I. Title. II. Series.

PN163.G45 $2007 \quad$ 070.5'20941 C2007-901488-7

University of Toronto Press acknowledges the financial assistance to its publishing program of the Canada Council for the Arts and the Ontario Arts Council.

This book has been published with the help of a grant from the Canadian Federation for the Humanities and Social Sciences, through the Aid to Scholarly Publications Programme, using funds provided by the Social Sciences and Humanities Research Council of Canada.

University of Toronto Press acknowledges the financial support for its publishing activities of the Government of Canada through the Book Publishing Industry Development Program (BPIDP). 
For F.W.E. 
This page intentionally left blank 